\title{
Modern Humans' Expansion in Eurasia: One Flew East...
}

\author{
Pavel M. Dolukhanov*
}

School of Historical Studies, Newcastle University, UK

\begin{abstract}
The initial expansion of anatomically modern humans (AMH) occurred during a hyperarid event in Africa that occurred 135-75 ka. Large-scale AMH spread in northern Eurasia started during the Middle Weichselian glacial maximum, and proceeded during the subsequent mild interstadial (60-40 ka ago). This expansion which encompassed the polar regions and southern Siberia proceeded at a remarkably rapid pace, suggesting the entire area being taken up by uniform 'periglacial' landscape, equally suitable for AMH habitation. The 'transitional' industries (Chatelperronian, Szeletian, Streletsian etc) have seen archaeological manifestations of early AMH expansion.
\end{abstract}

Key Words: Northern eurasia, anatomically modern humans (AMH), palaeolithic, heinrich events.

\section{INTRODUCTION}

There are two basic hypotheses regarding the origins of Anatomically Modern Humans (AMH). The first one known as a 'multiregional evolution' [1] is based on the apparent similarity of skeletal remains of Homo erectus and $H$. sapiens. Its proponents trace the origins of all modern populations back to an African source, whence it gradually spread over Eurasia. The observable regional variants are viewed as a consequence of environmental differences, emerging through genetic drift and bottlenecking. The second hypothesis known as 'Out-of-Africa' scenario asserts that modern humans evolved comparatively recently from a small population in Africa, which totally replaced the archaic hominids. In recent years new data pertinent to early manifestations of anatomically and behaviourally modern humans (AMH) became available from various parts of the former USSR. This, together with new evidence from other parts of the world that includes technologically advanced radiometric measurements, climatic modeling and molecular genetics, may sufficiently clarify the origins and subsequent dispersal of modern humans. The present paper aims at a critical assessment of newly available evidence and suggesting novel scenarios for early AMH expansion in Eurasia.

\section{ENVIRONMENT}

The initial emergence and the subsequent expansion of AMH occurred during marine isotope stages (MIS) 5d-2, which lasted 117-10 thousand years (ka) ago. This period corresponded to the Last Ice Age, known in Europe as 'Weichselian' and as 'Zyryanka' in Siberia. Considerable climate changes are recognisable throughout this period. The Greenland ice-core project (GRIP) and Greenland Ice Sheet Project (GISP) which included drilling through the base of the Greenland Ice Sheet provided the materials for stable isotope rerecords. They acknowledged signals of 24 high-

*Address correspondence to this author at the School of Historical Studies, Newcastle University, Armstrong Building, Newcastle, UK; Tel: +44 (0)191 281 1676; Fax: +44 (0)191 281 1676; E-mail pavel.dolukhanov@ncl.ac.uk frequency temperature oscillations for the last $120 \mathrm{ka}$, which became known as Dansgaard/Oeschger (DO) 'interstadial' events. These events which were generally by $5-6^{\circ} \mathrm{C}$ colder than now, lasted from 500 to 2000 years, and involved shifts in climate (from the warm to cold) of about $7^{\circ} \mathrm{C}[2,3]$. This time-span also included several 'Heinrich events' [4] recognised on the Atlantic Ocean bottom in the form of ice rafted debris. They were formed by icebergs drifting from the margins of the Laurentide ice lobe during the cold 'stadial' events. In calendar years these episodes are dated: H6 (60 ka); H5 (45 ka); H4 (38 ka); H3 (31 ka), H2 (21-ka) and H1 (15-14 ka).

The data regarding Late Pleistocene climate fluctuations are generally in agreement with recently available evidence of the ice sheet dynamics in northern Eurasia. According to now widely accepted scheme [5], this period included the Early (MIS 5d-a, 117-75 ka), Middle (MIS 4-3, 75-25 ka) and Late (MIS 2, 25-10 ka) subdivisions. During the Early Weichselian an extensive Barents-Kara Seas ice sheet was formed advancing to the Putorana Plateau in Siberia. In the west it merged with the Scandinavian ice sheet restricted to the Norwegian mainland, Finnish Lapland and northern Russian Karelia. The maximum extension of the ice sheets is estimated as c. $90 \mathrm{ka}$. During the Middle Weichselian glacial maximum (60-50 ka), the Barents Kara ice sheet readvanced onto the mainland covering the Mezen and Pechora river basins. At the same time, the lobe of the Scandinavian icesheet filled the entire Baltic Sea and advanced to Kola Peninsula, Finland and Denmark. This episode was largely coeval with $\mathrm{H6}$ event.

As show the pollen data and the 'biomic' modelling [6], the vegetation of ice-free Eurasia during both the colder and milder episodes consisted mainly of herbaceous coldresistant plants with a limited expansion of forests restricted to the Europe's south. On the East European Plain the colder episodes correspond to the establishment of 'cryo-xerotic' conditions, alternating with an intensive soil building during the milder episodes [7]. 
With the ocean level at c $75 \mathrm{~m}$ below the present one, the dry shelf was accessible for human migrations. Both the Black and Caspian Seas were mega-lakes separated from the Mediterranean Sea and each other [8]. The influx of melt water resulted in a gradual rise of the levels of these megalakes. The Caspian Sea culminated at 16-12 ka BP (the 'Khvalynian transgression') becoming connected with the Black Sea via the 'Manych spillway' [9].

\section{EAST EUROPEAN PLAIN}

During the course of MIS 5d-a, the southern part of the East European Plain and its mountainous fringes, notably the Crimea and the Caucasus, sustained considerable populations of Neanderthal humans. These are witnessed by the sites with Mousterian-type inventories in some cases (as in the Crimea and the Caucasus) associated with Neanderthals skeletal remains. Chabai [10] distinguishes three main periods of Mousterian occupations in the Crimean mountains: c. 125-60, $60-38$ and 38-<28-27 kyr BP.

The early manifestations of AMH in Europe are acknowledged by the appearance of sites with Upper Palaeolithic (UP) technologies. The fully developed UP industries classified as Aurignacian appear in the eastern Carpathian area at about $32.7 \mathrm{ka}$ [11]. A similar age (30-28 $\mathrm{ka} \mathrm{BP}$ ) has been obtained in the Crimea [10] and northern Caucasus [12]. Among its main attributes one note [13] the prevalence of prismatic blade technology with the common occurrence of UP-type tools, notably, end scrapers (and particularly, the carinated varieties), blade burins, notched, denticulated and scaled pieces (piéces ésquillées), retouched blades and points (particularly of Dufour, Font-Yves and Krems types), as well as varied bone and antler industries (split-base antler points being considered as the diagnostic tool). Significantly, early Aurignacian sites often include manifestations of symbolic behaviour, rock engravings, sculptured zoomorphic and anthropomorphic effigies and personal ornaments.

The earliest radiometric dates obtained with the use of various dating techniques in various parts of Europe suggest the age of oldest UP sites in Europe as in the order of 40-43 ka. Taking into account the possible uncertainty of radiometric dates Kozlowski [14] suggests that the spread of initial elements of UP technologies occurred in several waves during the time-span of $48-38 \mathrm{ka}$.

An early Upper Palaeolithic occupation is signaled for the central areas of East European Plain as exemplified by Kostenki sites on the River Don (Fig. 1(1)). The earliest UP layers have been reached in the lowermost strata of Kostenki 12 site, radiocarbon dated to $40-42$ and with OSL dates between 52 and $45 \mathrm{ka}$ [15]. Still more important evidence comes from the Kostenki 14 site, which level IVa produced a consistent series of radiocarbon measurements ranging from 36.5 to $32.6 \mathrm{ka}$ BP $[16,17]$. This level yielded a rich industry which included a typical UP tool-kit combined with archaic bifacial, mainly oval convex-flat implements. The level includes symbolic manifestations, including a head of a female figurine made of mammoth tusk (Fig. 2).

The sites of a comparable age have been identified in the extreme north-east of East European Plain, close to the Polar Circle (Fig. 1(2)). A series of radiocarbon dates obtained for bones and mammoth tusks from the Byzovaya site, yielded the age in the range of of 25.5-30.0 ka, with one sample showing the age of $33 \pm 2$ ka [18]. At the site of Mamontovaya Kur'ya still further to the north, bones of large mammals and artefacts, which included incised mammoth tusk (Fig. 3) were found in river-channel deposits.

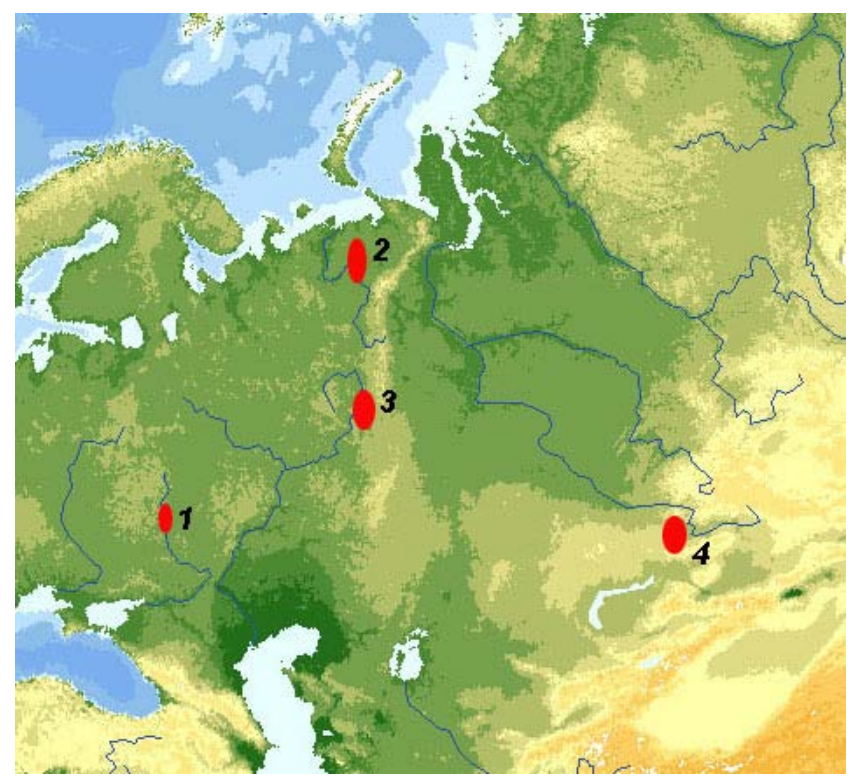

Fig. (1). Location of major Palaeolithic sites on East European Plain and southern Siberia; (1) - Kostenki area; (2) - ByzovayaMamontova Kurya; (3) - Chusovaya; (4) - Altai Mountains.

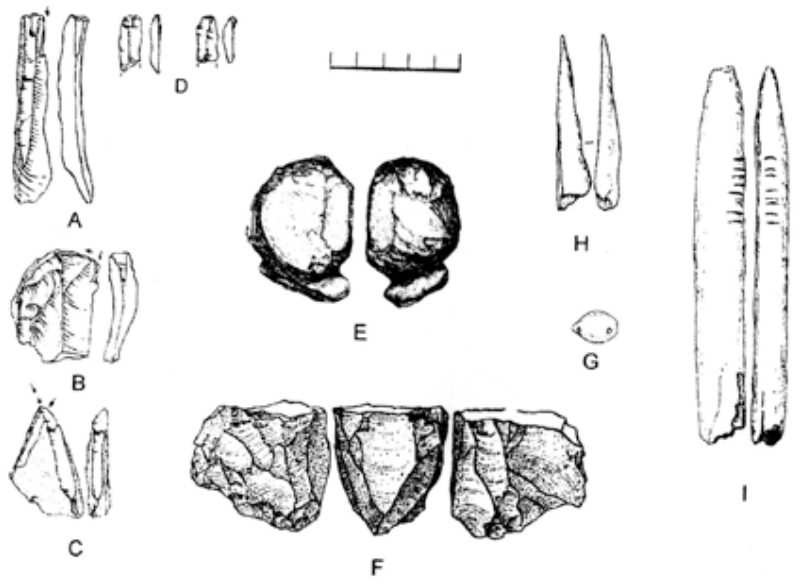

Fig. (2). Artifacts from Kostenki 14 site, layer (A-C burins; D blade fragments; $\mathbf{E}$ - ivory anthropomorphic figurine; $\mathbf{F}$ - core; $\mathbf{G}$ perforated shell; H - bone awl; I - incised bone point) [15].

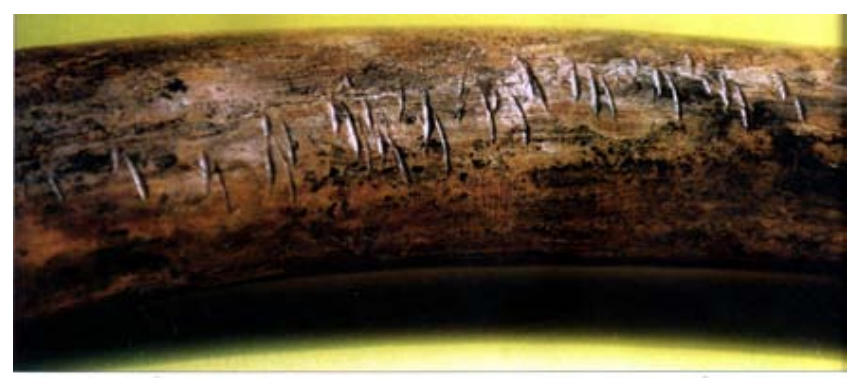

Fig. (3). Incised mammoth tusk from Mamontovaya Kurya site [19]. 
Radiocarbon dated bones yielded the age of 37-35 ka [19]. A group of early UP sites has been found on the Chusovaya River in the western foothills of the Ural Mountains (Fig. 1(3)). One of the sites, Zaozer'ye yielded a series of radiocarbon dates in the range of 31.5-30.7 ka [20].

\section{SIBERIA}

Mousterian industries were reportedly identified in the Altai Mountains, both in the open-air sites (Kara-Bom and Ust-Karakol-I) and rock shelters (Ust-Kan, Strashnaya, Denisova, Okladnikov) [18, 19] (Fig. 1(4)).

The Okladnikov Cave in the Altai Mountains yielded several human teeth and postcranial bones. The teeth are radiocarbon dated to $37750 \pm 750$ and $43700+1100 /-1300$ years BP [25]. The attribution of these skeletal remains caused a considerable controversy. Turner [26] diagnosed the premolar from the Okladnikov Cave as similar to those of European Neanderthals. Alekseev [27], (1998) and Shpakova. [28], on the other hand, found no deviations from the morphology of modern humans. Krause et al. [25] based on recently performed comparison of mitochondrial DNA sequences concluded that that the Okladnilov Cave skeletal remains 'belonged to a population related to European and western Asian Neanderthals'.

Several sites in southern Siberia yielded the 'transitional' industries which are referred to as 'the initial Upper Palaeolithic' (IUP) $[21,22,23,24]$. These industries combine the Upper Palaeolithic technology with archaic elements, bone and antler tools and ornaments. These sites dated to $42-25 \mathrm{ka}$ BP have been identified in the Altai Mountains, along the Angara River and in the Bailkal Lake area [29]. The sequence of Kara-Bom includes the levels attributed to Mousterian and 'transitional' to Upper Palaeolithic industries, which yielded similar radiocarbon dates $(>44 \mathrm{ka}$ and $43200 \pm 1500$ respectively) (Fig. 4).

\section{DISCUSSION}

The radiometric age obtained for skeletal remains of early modern humans and related material culture is much older in Africa and the Near East, than anywhere else in the world. The AMH skeletal remains in Ethiopia show the age of $130-195 \mathrm{ka}[30,31]$. The age of $120-90 \mathrm{ka}$ is attested for samples of South African humans from the Klasies River Mouth [32].

A similar age has also been obtained for early modern human sites in the Near East. The cave sites of Qafzeh and Skhul which contain early forms of Homo sapiens have been dated with the use of TL technique to ca 80 - 120ka [33,34]. Recently performed U and ESR analyses of bones and teeth from AMH burial at Skhul yielded the age in the order of 135-100 ka [35].

Both archaeological and genetic data [36,37] strongly signal the large-scale population expansion of early AMH groups. The causal mechanism of large-scale migrations of early modern humans remains a debatable issue. There is little doubt that the adverse environment and food shortages played a significant role in this process. Observations of baboons in their natural habitats and the studies on behavioural ecology of foragers' communities [38,39,40,41] equally suggest that the climate changes leading to the depleted bioproductivity resulted in an increased residential mobility, and an extension of hunting areas. The existing palaeoclimate records [42] indicate a prolonged period of 'megadroughts' that lasted between 135 and $75 \mathrm{ka}$ and virtually coincided with the initial expansion of AMH. One may reasonably suggest that the adverse environment triggered a large-scale human displacement in quest of landscapes better provided with food resources. The ensuing increase in effective moisture punctuated by several episodes of desiccation, equally acknowledgeable in palaeoclimatic records created additional stimuli for population explosion and mobility.
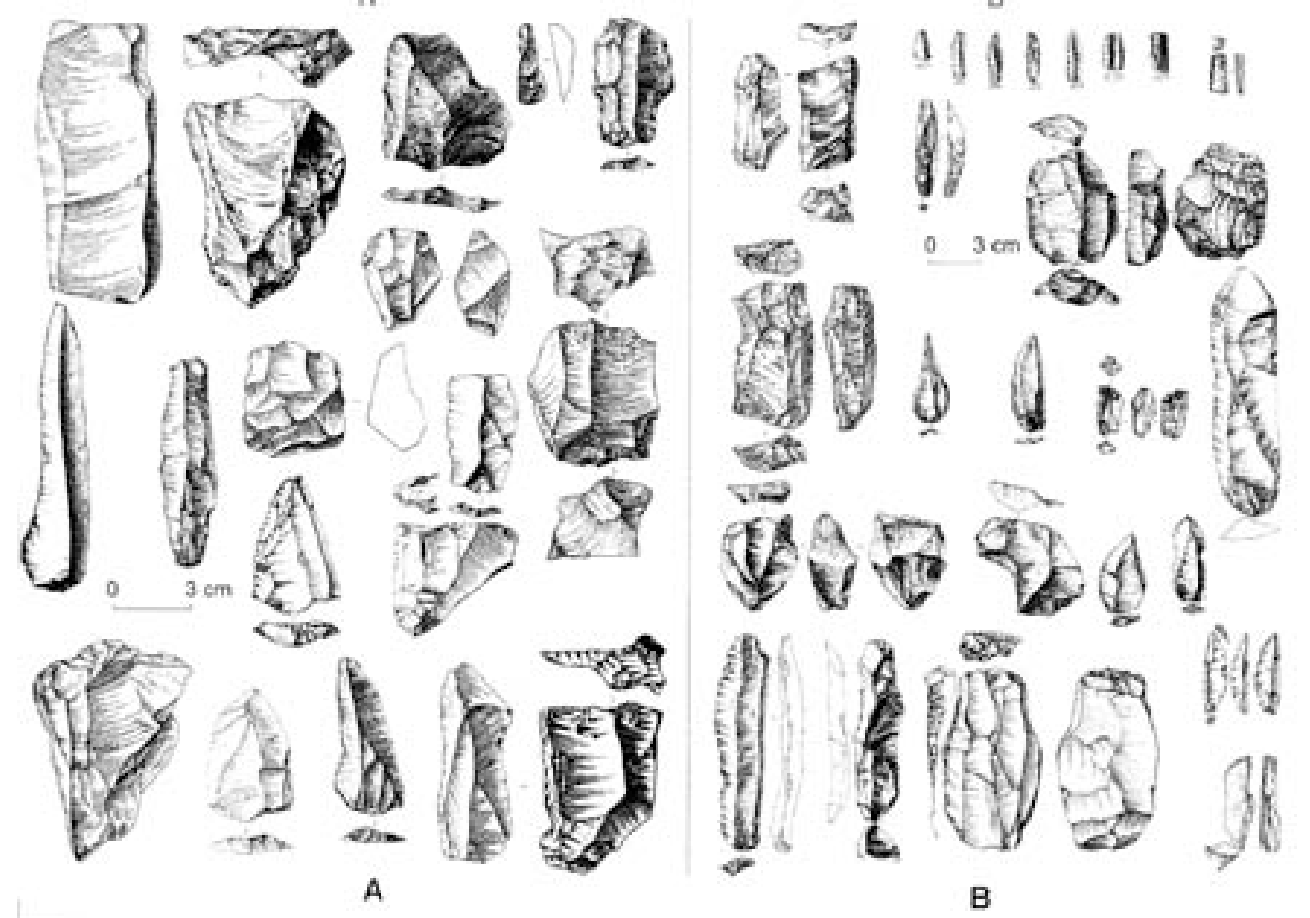

Fig. (4). Stone implements from Kara-Bom site: Mousterian layer (A), and Initial Upper Palaeolithic layer (B); [21]. 
Another debatable problem concerns the cohabitation and interactions between the populations of AMH and Neanderthals. Differently to Homo erectus and H. sapiens, Neanderthals most likely developed in Europe where they are acknowledgeable at least since MIS 7. The Neanderthals prolonged coexistence with the AMS in the Near East and Europe is firmly confirmed. Both the ESR and TL dates for Neanderthal sites at Kebara and Amud fall into the range of 50-65 ka. Even younger age (32-33 ka) has been obtained for Neanderthal specimens from Vindija Cave in Croatia [43]. The southern part of the East European Plain and its mountainous fringes, notably the Crimea and the Caucasus, include a high density of Mousterian sites in several cases associated with Neanderthals skeletal remains, which existed at least until 28-27 ka [10].

Neanderthal populations in Europe were always associated with Mousterian industries. Significantly, the early Homo sapiens sites in the Near East were equally associated with the 'Levantine Mousterian (of Levallois facies)'. Still more importantly, the both population exhibit essentially similar symbolic behaviour: primitive modern humans were buried at Skhul and Qafzeh, while Neanderthals, at the Tabun, Kebara, Amud and Dederiyeh caves [44].

The DNA sequencing $[45,47]$ apparently shows that the Neanderthals were a separate lineage or species that did not mix with Homo sapiens. This view is contested by Templeton [47], who argues that the 'third out-of-Africa event' was characterised by AMH interbreeding with ancestral populations. This latter view is more in consistence with archaeological evidence

The assessment of Neanderthals' survival and their possible coexistence with the AMH is closely related to the problem of 'transitional industries'. Such industries combining the archaic technology with UP elements have been recognised in the Near East in the form of Ahmarian [48]. To the same category are classified several assemblages in the Balkans which include cave sites in Bulgaria: Temnata I, stratum IV and Bacho Kiro, stratum 4, with the radiometric age of $43-36 \mathrm{ka}$ [14]. The latter site includes artistic manifestations: a plate with incised geometric ornament at Temnata (stratum IV) and perforated animal teeth at Bacho Kiro, stratum 11.

The transitional industries include such entities as Châtelperronian in Western Europe, Uluzzian in Italy, Szeletian and Bohunician in Central Europe. All these industries, albeit clearly distinct, share certain common features: the basic Levalloisian technology with the common occurrence of convex backed bladelets [14]. The Châtelperronian in France and northern Spain is unambiguously associated with ornaments, notably, decorated bone tools.

At Kostenki 14 site on the River Don in Russia, the level $14 \mathrm{a}$ radiocarbon dated to 36.5 to $32.6 \mathrm{ky} \mathrm{BP}$, yielded prismatic core blades, bladlets, end-scrapers and piéces ésquillées combined with archaic small-size bifaces. [16,17]. This and similar assemblages are assigned to the 'Streletsian' Culture in Kostenki and areas further south. Its elements are acknowledgeable in Early UP industries in the Russia's North-East (Mamontovaya Kurya and Zaozer'ye). Further to the east one may find its analogies in 'Kara-Bom'-type industries in the Altai Mountains [49]. All these industries show the combination of archaic and advanced elements in the toolkit, diversified subsistence, evidence of long-range contacts and the occurrence of symbolic objects.

To the same category one may classify the Middle Stone Ages (MSA) industries of Africa. The discovery of symbolic objects at Blombos Cave in South Africa's Cape Province is highly significant. The finds include perforated Nassarius kraussianus shells and fragments of red ochre with incised geometric design (Fig. 5) [50,51]. Perforated marine shells with residues of red pigment have been discovered in Grotte des Pigeons in Morocco in a layer dated to $82 \mathrm{ka}$ [52].

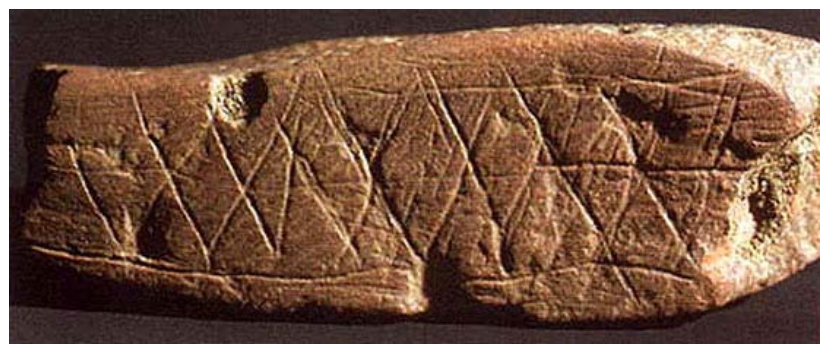

Fig. (5). Engraved ochre from Blombos Cave, Southern Africa [50].

Further examples of perforated shells have been reported from early AMH sites in Algeria (Oued Jebbana) and Isreal (Skhul). Remarkably, the geometric ornaments similar to those from Blombos Cave are common in the ornamented bone industry of Upper Palaeolithic sites of Eastern European Plain (such as Yudinovo, Timonovka and Mezherich [53]. Marshak [54] considered them as 'time notations' and an evidence of human-like cognitive behaviour (Fig. 6).

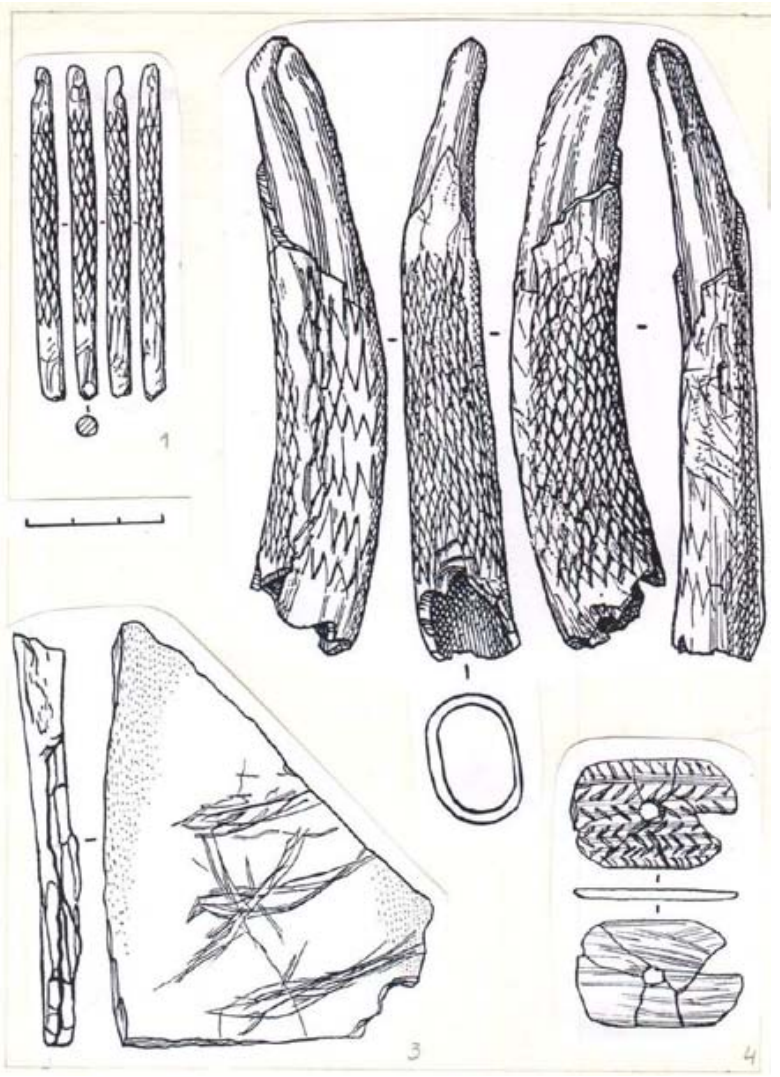

Fig. (6). Engraved antlers from Yudinovo site [53]. 
Summing up the existing evidence, one might suggest the following scenario of early AMH dispersal (Fig. 7). The initial expansion of early modern humans occurred during a hyperarid event in Africa that occurred 135-75 ka. One might visualise the trajectory of early $\mathrm{AMH}$ dispersal, which lead from eastern Africa to the Levant mostly following the East African Rift. Likewise in the case of initial spread of tool-making hominids, these landscapes offered for early modern humans environmental mosaics sufficiently rich in food and water resources [55].

Levant was the most likely area of active interaction and interbreeding between the Neandethals and AMH. This resulted in mutual cultural borrowing: the acceptance of Mousterian technology by modern humans and elements of symbolic behaviour by Neanderthals (burial rite personal ornaments).

The further spread of AMH from the Levant occurred during the dry episode coeval with $\mathrm{H} 6$ event, ca $60 \mathrm{ky}$. It has been remarked that the onset of cold and dry climate in the northern latitudes corresponded to the establishment of a dry and cool climate in monsoon-affected areas of western and south-eastern Asia, as well as northern and eastern Africa. In the Levant this took the form of low precipitation and expansion of deserts [56].

In the Balkans the expanding $\mathrm{AMH}$ groups divided into two branches, one following into Central and Western Europe, and another to East European Plain. The expansion of modern humans in northern Eurasia including its polar regions and southern Siberia proceeded at a remarkably rapid pace, estimated by Mellars [57] as $0.4 \mathrm{~km}$ per year. This rapid expansion occurred during the Middle Weichselian glacial maximum (60-50 ka), coeval with H6 event. This further suggests that at that time the vast areas of northern Eurasia were taken up by uniform 'periglacial' landscape, equally suitable for $\mathrm{AMH}$ habitation.

The 'transitional' industries were archaeological manifestations of this rapid AMH expansion. These industries which featured cultural diversity and considerable typological and technological variability [49] developed on the base of an active cultural interaction between the expanding Homo sapiens and indigenous populations. In most cases these industries are firmly associated with skeletal remains of modern humans. The occurrence of Neanderthal skeletal remains at Châtelperronian sites Saint-Césaire and Arcy-sur-Cure can be viewed as an indication of special positions held by $\mathrm{Ne}$ anderthal individuals within the sapiens-dominated communities.

The mtDNA sequencing of skeletal remains from Okladnikov Cave in the Altai Mountains reportedly demonstrated their affinity to a population 'related to European and western Asian Neanderthals' [25]. Not mentioning the noticeable contamination of fossil bones with modern human DNA which seriously affects the results of this analysis, this might have resulted from the interbreeding of expanding modern humans with Neanderthals as suggested by Templeton [42].

It has been remarked [58] that although the Neanderthals apparently preferred warmer climatic conditions, there is strong evidence that the spatial patterning of Neanderthals and early AMH was very similar. As it seems, the main causes of Neanderthal extinctions should be sought in the social, cognitive and genetic sphere, AMH forming more copious aggregations with an open gene flow. AMH were much better equipped for the information exchange and symbolic communication as witnessed by the systematic occurrence of symbolic objects and works of art from the very early stages of their existence. In the case of glacial advance, small Neanderthal groups became increasingly isolated and vulnerable to genetic diseases.

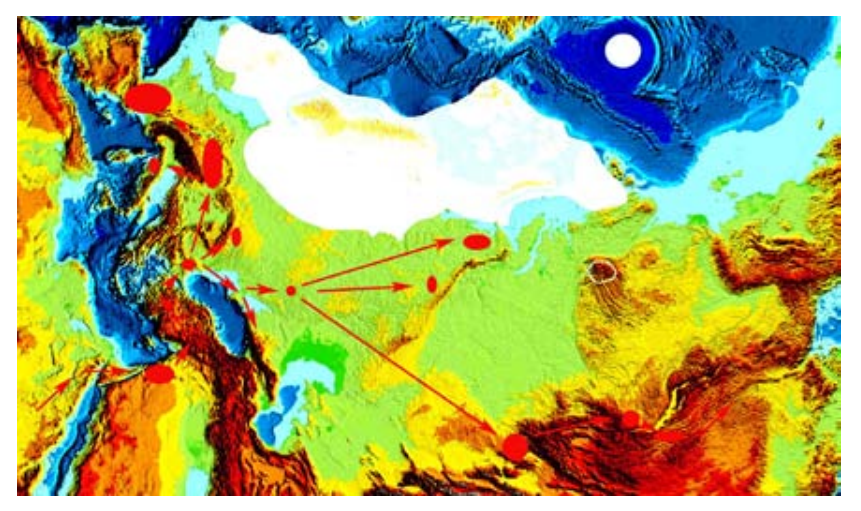

Fig. (7). Trajectories of early AMH dispersal.

Key: white area: ice-sheet, after [5]; red arrows: migratory routes; red ellipses: clusters of sites.

\section{CONCLUSIONS}

Early modern humans initially emerged in Africa during a hyperarid event that occurred 135-75 ka.

Large-scale AMH expansion in northern Eurasia occurred during Middle Weichselian glacial maximum, and the subsequent mild interstadial (60-40 ka ago);

The expanding human populations culturally and genetically interbred with autochthonous Neanderthal groups, which archaeologically became conspicuous as 'transitional industries'.

The final demise of Neanderthals resulted from their geographical isolation and vulnerability to genetic diseases.

\section{ACKNOWLEDGEMENT}

This project was partially sponsored by FEPRE European Community Grant.

\section{REFERENCES}

[1] Wolpoff MH, Wu XZ AG, Thorne AG. Modern Homo sapiens origins: a general theory of hominid evolution involving the fossil evidence from eastern Asia. In: Smith FH, Spencer F, Eds. The Origins of Modern Humans. New York, Allan R. Liss, 1984; 411484.

[2] Dansgaard W, Johnsen SJ, Clausen HB, et al. Evidence for general instability of past climate from a $250 \mathrm{kyr}$ ice core. Nature 1993; 364: 218-219.

[3] Grootes PM, Stuiver M, White MJWC, Johnsen S, Jouzel J. Comparison of oxygen isotope records from the GISP2 and GRIP Greenland ice cores. Nature 1993; 366: 552-4.

[4] Hemming SR. Heinrich events: massive late Pleistocene detritus layers of the North Atlantic and their global imprint. Reviews of Geophysics 2004; 42: RG1005, doi:10.1029/2003RG000128.

[5] Svendsen J, Alexanderson H, Astakhov V, et al. Late Quaternary ice sheet history of Northern Eurasia. Quat Sci Rev 2004; 23: 1229 1271 .

[6] Huntley B, Allen JRM. Glacial environments III: palaeo-vegetation patterns in Last Glacial Europe. In van Andel TH, Davies W, Eds. 
Neanderthals and Modern Humans in the European landscapes during the Last Glaciation: archaeological results of the Stage 3 Project. Cambridge, McDonald Institute for Archaeological Research, 2003; 79-102.

[7] Velichko AA. Late Pleistocene palaeoclimatic reconstructions. In: Velichko AA, Ed. Late Quaternary Environments of the Soviet Union. Minneapolis: University of Minnesota Press, 1984; 261-285.

[8] Konikov EG. Sea-level fluctuations and coastline migration in the northwestern Black Sea area over the last $18 \mathrm{yr}$ based on highresolution lithological-genetic analysis of sediment architecture. In: Yanko-Hombach V, Gilbert AS, Panin N, Dolukhanov P, Eds. The Black Sea Flood Question: Changes in Coastline, Climate and $\mathrm{Hu}-$ man Adaptations. Dodrecht, Springer 2007; 405-436.

[9] Chepalyga AL. The late glacial great flood in the Ponto-Caspian basin. In: Yanko-Hombach V, Gilbert AS, Panin N, Dolukhanov P, Eds. The Black Sea Flood Question: Changes in Coastline, Climate and Human Adaptations. Dodrecht, Springer 2007; 119-148.

[10] Chabai VP. The Middle Palaeolithic and Early Upper Palaeolithic in the Northern Black Sea Region. In: Yanko-Hombach V, Gilbert AS, Panin N, Dolukhanov P, Eds. The Black Sea Flood Question: Changes in Coastline, Climate and Human Adaptations. Dodrecht, Springer 2007; 279-296.

[11] Noiret P. Upper Palaeolithic in Moldavia. L'Anthropologie 2004: 108 (3-4): 33-29.

[12] Golovanova LV, Hoffecker JF, Kharitonov VM, Romanova, GP. Mezmaiskaya Cave: A Neanderthal Occupation in the Northern Caucasus. Curr Anthropol 1999; 40: 77-86.

[13] Djindjian F, Kozlowski J, Otte M. Le Paléolithique supérieur en Europe. Paris, Arman Colin 1999.

[14] Kozlowski JK. Paléolithique supérieur et Mésolithique en Méditerranée. L'Anthropologie 2005; 109: 520-540.

[15] Anikovich MV, Sinitsyn AA, Hoffecker JF, et al. Early upper palaeolithic in eastern europe and implications for the dispersal of modern humans. Science 2007; 315: 223-226.

[16] Sinitsyn AA. The most ancient sites of Kostenki in the context of the Initial Upper Palaeolithjic of northern Eurasia. In Zilhão J, D'Errico F, Eds. The Chronology of the Aurignacian and the Transitional Technocomplexes. Proceedings of XIV Congress of UISPP, Trabalhos de Arqueologia 2003; 33: 89-107.

[17] Haesaerts P, Damblon F, Sinitsyn A, van der Plicht J. Kostenki 14 (Voronezh, Central Russia): new data on stratigraphy and radiocarbon chronology. Actes of the XIV UISPP Congress, BAR International Series, Oxford 2004; 1240: 169-80.

[18] Mangerud J, Astakhov V, Svendsen JI. The extent of the barentskara ice sheet during the last glacial maximum. Quat Sci Rev 2002; 21: 111-9.

[19] Pavlov P, Svendsen JI, Indrelid S. Human presence in the European arctic nearly 40,000 years ago. Nature 2001; 413: 64-7.

[20] Pavlov PYu. Rannyaya pora verhnego paleolita na severo-vostoke Evropy [An early stage of Upper Palaeolithic in North-Eastern Europe]. Syktyvkar, Komy Research Centre of Russian Academy of Sciences, 2004.

[21] Derevianko AP. The Middle to Upper Paleolithic transition in the Altai (Mongolia and Siberia). Archaeol Ethnol Anthropol Eurasia $2001 ; 21(3)$ : $70-103$.

[22] Derevianko AP, Shunkov MV. Formation of the Upper Palaeolithic traditions in the Altai. Archaeol Ethnol Anthropol Eurasia 2004; 5 (3): $125-138$.

[23] Derevyanko AP, Petrin VT, Rybin EP. Harakter perehoda ot must'e k verhnemu paleolitu na Altae (po materialam stoyanki Kara-Bom) [The character of transition from the Mousterian to Upper Palaeolithic in the Altai Mountains, on the materials of Kara-Bom site]. Arheologiya Etnografiya Antropologiya Evrazii 2000; 2 (2): 33-52.

[24] Goebel T. Human colonization of Siberia and peopling of the Americas: an Ecological Approach. Evolut Anthropol 1999; 8(6): 208-27.

[25] Krause J, Orlando Serre LD, Viola B, et al. Neanderthals in central Asia and Siberia. Nature 2007; 449: 902-4.

[26] Turner CG. Palaeolithic Siberian dentition from Denisova and Okladnikov caves, Altaiskiy Kray, USSR. Curr Res Pleistocene 1990; 7: 65-6.

[27] Alexeev VP. The physical specificities of Paleolithic hominids in Siberia. In: Derevanko A.P.Ed. The Paleolithic of Siberia. Urbana: University of Illinois Press, 1998; 329-35.

[28] Shpakova EG. Odontologicheskie materially perioda paleolita na territorii Sibiri [Odcotological materials of Palaeolithic period from the territory of Siberia]. Arheologiya, etnografiya antoropoliya Evrazii 2001; 4: 64-76.

[29] Vasil'ev SA, Kuzmin YV, Orlova LA, Dement'ev VN. Radiocarbon-based chronology of the Palaeolithic in Siberia and its relevance to the peopling of the New World. Radiocarbon 2002; 44(2): 266-75.

[30] Clark JD. Stratigraphical, chronological and behavioural contexts of the Pleistocene Homo sapiens from Middle Awash, Ethiopia. Nature 2003; 423: 747-52.

[31] McDougall I, Brown FH, Fleagle FG. Stratigraphic placement and the age of the Modern Humans from Kibish, Ethiopia. Nature 2005; 433: 733-6.

[32] Rightmere GP, Deacon HJ. Comparative studies of Late Pleistocene human remains from Klasies River, South Africa. J Hum Evol 1991; 20 (2): 131-56.

[33] Valladas Y, Mercier N, Joron J-L, Reyss J-L. GIF Laboratory dates for Middle Palaeolithic Levant. In: Akazawa T, Aoki K, Bar-Yosef O. Neandertals and Modern Humans in Western Asia. Mew York \& London, Plenum Press, 1998; 461-482.

[34] Bar-Yosef O, Arnold M, Mercier N, et al. The dating of the Upper Palaeolithic layers in Kebara Cave, Mount Carmel. J Archaeol Sci 1996; 23(2): 297-306.

[35] Grün R, Stringer C, McDermott F, Nathan R, Porat N, Robertson S, Taylor L, Mortimer G, Eggins, McCulloch M. U-series and ESR analyses of bones and teeth relating to the human burials from Skhul. J Hum Evol 2005; 43: 316-34.

[36] Rogers AR. Genetic evidence for a Pleistocene population explosion. Evolution 1995; 49: 608-15.

[37] Excoffier L. Human demographic history: refining the recent African origin model. Curr Opin Gen Dev 2002; 12(6): 675-82.

[38] Binford LR. Constructing Frames of Reference: an Analytical Method for Archaeological Theory-Building Using HunterGatherer and Environmental Dataset. Berkley, University of California Press, 2001.

[39] Kelly L. Hunter-gatherer mobility strategy. J Anthropol Res 1983; 39: 277-306.

[40] McCall G. Behavioural ecological models of lithic technological change during the later Middle Stone Age of Southern Africa. J Archaeol Sci 2007; 34 (10): 1738-51.

[41] Lee PC. Ecological influences on relations and social structure. In: Hinde RA, Ed. Primate Social Relationships: an Integrated Approach. Oxford, Blackwell 1983; 225-229.

[42] Scholz CA, Johnson TC, Cohen AS, et al. East African megadroughts between 135 and 75 thousand years ago and bearing on early-modern human origins. Proceedings of the National Academy of Science published online on September 4, 2007, 10.1073/pnas. 0703874104.

[43] Higham T, Bronk Ramsey C, Karavanic I, Smith IFH, Trinkaus E. Revised direct radiocarbon dating of the Vindija $\mathrm{G}_{1}$ Upper Paleolithic Neandertals. Proc Natl Acad Sci 2006; 103 (3): 553-7.

[44] Bar-Yosef O. The Middle and Early Upper Paleolithic in Southwest Asia and Neighbouring Regions, In: Bar-Yosef O, Pilbeam D, Eds. The Geography of Neandertals and Modern Humans in Europe and the Greater Mediterranean, Peabody Museum Bulletin 8, Peabody Museum of Archaeology and Ethnology, Harvard University Press, Cambridge, Massachusetts, USA 2000; 107-156.

[45] Krings M, Stone A, Schmitz RW, Krainitzki H, Stoneking M, Pääbo S. Neandertal DNA sequences and the origin of modern humans. Cell 1997; 90: 19-30.

[46] Ovchinnikov A, Gotherstrom A, Romanova GP, Kharitonov VM, Linden K, Goodwin W. Molecular analysis of Neanderthal DNA from the northern Caucasus. Nature 2000; 404: 490-3.

[47] Templeton AR. Haplotype trees and modern human origins. Yearbook Phys Anthropol 2005; 48: 33-59.

[48] Kuhn S. In what sense is the Levantine Initial Upper Palaeolithic a 'transitional industry'? In: Zilhão J, D’Errico F, Eds. The Chronology of the Aurignacian and the Transitional Technocomplexes. Proceedings of XIV Congress of UISPP, Trabalhos de Arqueologia 2003; 61-70.

[49] Sinitsyn AA. Skhodstvo i razlichie kara-bomnskogo plasta verkhnego paleolita Vostochnoi Evropy [Similarity and distinction within the Kara-Bom level of East European Upper Palaeolithic] In: Derevyanko AP, Shunkov MV, Eds. Aktual'nye voprosy evraziiskogo palaeolitovedeniya [Actual Questions of Eurasian Palaeolithic Studies] Novosibirsk, Institute of Archaeology and Ethnography, 2005; 179-184. 
[50] Henshilwood C, d'Errico F, Yates R, et al. Emergence of modern human behaviour. Middle Stone Age engravings from Southern Africa. Science 2003; 295: 1278-80.

[51] Henshilwood CS, Marean CW. The origin of modern human behaviour. Curr Anthropol 2003; 44(5): 627-751.

[52] Bouzouggar A, Barton N, Vanhaeren M, et al. 82,000-year-old shell beads from North Africa and implications for the origins of modern human behaviour. Proc Natl Acad Sci 2007; 104: 99649969.

[53] Grigor'eva GV. Ukrasheniya i ornamentorovannye bivni iz verhnepalaeoliticheskogo poseleniya Yudinovo [Adornments and ornamented antlers from the Upper Palaeolithic settlement of Yudinovo]. Stratum Plus 2000; 1: 326-31.

[54] Marshak A. The Roots of Civilization. The Cognitive Beginning of Man's First Art, Symbol and Notations. New York, McGraw Hill 1972.
[55] King G, Bailey G. Neotectonics and human evolution. Antiquity 2006; 80: 265-286.

[56] Abdulkader M, Abed AM, Yaghan R. On the palaeoclimate of Jordan during the last glacial maximum. Palaeogeogr Palaeoclimatol Palaeoecol 2000; 160 (1-2): 23-33.

[57] Mellars P. A new radiocarbon revolution and the dispersal of modern humans. Nature 2006; 429: 931-5.

[58] Davies W, Gollop P. The human presence in Europe during the Last Glacial period II: climate tolerance and climate preference of Mid- and Late Glacial hominids. In: van Andel TH, Davies W, Eds. Neanderthals and Modern Humans in the European landscapes during the Last Glaciation: archaeological results of the Stage 3 Project. Cambridge, McDonald Institute for Archaeological Research $2003 ; 131-46$

(C) Pavel M. Dolukhanov; Licensee Bentham Open.

This is an open access article distributed under the terms of the Creative Commons Attribution License (http://creativecommons.org/licenses/by/2.5/), which permits unrestrictive use, distribution, and reproduction in any medium, provided the original work is properly cited. 